\title{
Comparative Study of Hematological Disorders of Antiviral Treatments in Algerian Chronic Hepatitis C Patients
}

\author{
Kamilia Guedri $^{1}$, Aziez Chettoum ${ }^{2}$, Nawel Attoui ${ }^{3}$ \\ ${ }^{1}$ Department of Biology, University Larbi Tebessi, Tebessa, Algeria \\ ${ }^{2}$ Department of Biology Animal, University Mentouri, Constantine, Algeria \\ ${ }^{3}$ Department of Biology, University Tahri Mohamed, Bechar, Algeria
}

Email address:

guedrikamilia@yahoo.fr (K. Guedri)

\section{To cite this article:}

Kamilia Guedri, Aziez Chettoum, Nawel Attoui. Comparative Study of Hematological Disorders of Antiviral Treatments in Algerian Chronic Hepatitis C Patients. Journal of Health and Environmental Research. Vol. 5, No. 1, 2019, pp. 24-31. doi: $10.11648 /$ j.jher.20190501.14

Received: January 22, 2019; Accepted: March 6, 2019; Published: March 21, 2019

\begin{abstract}
Viral hepatitis C (HCV) is a major health problem that affects important number of people around the world, the emergence of new direct antiviral treatments is a real therapeutic revolution to days it allows the cure hepatitis $\mathrm{C}$ in the majority of patients, but these treatments is accompanied by numerous side effects. Sofosbuvir, Pegylated interferon and Ribavirin are the standard care for the treatment of chronic hepatitis $\mathrm{C}$ in Algeria. In this study, we are interesting to investigate hematological toxicity of Antiviral treatment in Algerian patients with chronic hepatitis C. We carried out a comparative study, which involved 300 men and women Algerian at different ages. The determination of the various Epidemiological, Hematological, biochemical (AST, ALT, Glycemia) and virological (Viral load) parameters was performed. The analysis of 300 data shows that the infection with hepatitis $\mathrm{C}$ affects the age group between (46- 65 years) with a percentage of $67 \%$ with a female predominance $82 \%$ and a clear predominance of genotype $1 \mathrm{~b}$ with a percentage (89\%), Dual therapy (Sofosbuvir + Ribavirin) and triple therapy (Sofosbuvir + Ribavirin + Pegylated interferon) induce a high hematological toxicity - Hemolytic anemia ( revealed by a decrease of the number of Red blood cell and Hemoglobin level, as well as the percentage of hematocrit and the increase of mean corpuscular volume that induced the increase of red blood cell masse and the expansion) Thrombocytopenia (revealed by the decrease in the number of platelets ) and leukopenia (translated by the decrease in the number of White blood cells and lymphocytes as well as monocytes, and a very significant increase in granulocytes) whereas in monotherapy (Sofosbuvir) a low toxicity was noticed, the Patients how receiving triple therapy (Sofosbuvir + Ribavirin + Pegylated interferon) can be developing diabetes mellitus. Antiviral treatments were significantly induced hemolytic anemia, leucopenia and thrombopenia in Algerian patients with chronic hepatitis C.
\end{abstract}

Keywords: Sofosbuvir, Ribavirin, Pegylated Interferon, Hepatitis C, Hematological Toxicity

\section{Introduction}

Chronic HCV infection is associated with substantial morbidity and mortality, with liver-related complications including cirrhosis, liver failure and hepatocellular carcinoma (HCC) [1]. The goal of antiviral therapy is to prevent these complications by achieving viral eradication. This is defined as undetectable HCV RNA 12 weeks after treatment cessation, also called a sustained virologic response (SVR) $[2,3]$. The recent introduction of direct-acting antivirals (DAAs) has revolutionised HCV therapy and made viral cure, which is associated with improved quality of life, a reality in the vast majority of patients [4, 5]. Even in patients in whom interferon-based treatment has traditionally been difficult or contraindicated, including those with decompensated cirrhosis or severe kidney disease, HCV can now be eradicated with minimal toxicity and good overall tolerability [6, 7]. Moreover, large scale post-marketing studies have shown that data from clinical trials can be replicated in the real world setting with high overall efficacy and few safety concerns [8, 9] There's increasing evidence that viral eradication following DAA therapy is associated 
with a significant decrease in liver-related morbidity and mortality, and the adverse extra hepatic sequelae of HCV infection, while being associated with an increase in healthrelated quality of life. $[10,11]$

On the other hand, Hepatitis $\mathrm{C}$ virus (HCV) antiviral therapy entails a long treatment course, as well as significant side effects that can lead to medication non-adherence and premature termination of treatments.

It has been reported that antiviral treatments of $\mathrm{HCV}$ was associated with many side effects [12], such as hematologic toxicity that require monitoring include neutropenia and thrombocytopenia $[13,14]$

\section{Aim of the review}

The combination therapy of antiviral Peg-interferon, Ribavirin and Sofosbuvir has evolved as one of the better treatments for hepatitis C. In spite of its success in controlling hepatitis $\mathrm{C}$ infection, it has also been associated with treatment-related adverse side effects. The objective of this study is to investigate the hematological risks associated with antiviral treatment in Algerian patients with chronic viral hepatitis $\mathrm{C}$.

\section{Method}

\subsection{Target Population}

Comparative study was done in eastern Algeria in 50 control and 50 patients affected by $\mathrm{HCV}$ and 300 patients with viral hepatitis $C$ and received antiviral therapy by oral administration for 12 weeks with Sofosbuvir (400mg-90mg (1tablet/day), Ribavirin 200mg [1200mg <poids $75 \mathrm{Kg}>$ $1000 \mathrm{mg}$ ] and INF peg (dos $1 \mathrm{mg} / \mathrm{Kg} /$ week)

Treated HCV Patients were classified into three groups:

Group 1 which included 100 patients who received sofosbuvir

Group 2 which included 100 patients who received (Sofosbuvir+ Ribavirin)

Group 3 which included 100 patients who received Triple therapy (Sofosbuvir+ Ribavirin+Pegylated interferon)

\subsection{Pre-treatment Evaluation}

Complete history taking (Age, sex, genotype, disease history) and thorough clinical examination.

\subsubsection{Biological Examination}

Complete blood count ( $\mathrm{CBC}$ ) was carried out using the fully automated cell counter Abacus 380 with 19 parameters

\subsubsection{Virological Examination}

Viral load (RT-PCR): The technique used for qualitative research of HCV RNA is RT-PCR (Polymerase Chain Reaction in real time), It is a qualitative or quantitative test for measuring the viral load, RT-PCR is very sensitive since the detection threshold of the viral load is up to $10 \mu \mathrm{l} / \mathrm{ml}$. Its specificity is 97 to $99 \%$. This test makes it possible to identify the viral RNA in a week after the contamination.

Quantitative RT-PCR accurately measures the viral load of the infected patient. Quantification is performed using HCVspecific fluorescent probes applied to the PCR amplification product.

Real-time PCR uses the general principle of conventional PCR with a difference, an amplification measured throughout the reaction.

RNA is first extracted and retranscribed by an enzyme called reverse transcriptase, which allows the synthesis of complementary DNA (cDNA). The latter is then used to perform a PCR. The RT-PCR can be done in a particular device (Abbott m2000rt (Amplifier) + Abbott m2000sp (Extractor)) which allows to view in real time the synthesis of DNA fragments. For this, fluorescent molecules that bind to the DNA are used. It allows to follow continuously ("in real time") the PCR amplification process by detecting the fluorescence emitted by neo-formed PCR products. The fluorescence of the sample increases proportionally to the number of DNA molecules.

\subsubsection{Serological Examination}

Laboratory investigations:-HCV Ab was carried out using fully automated ELISA (Abbott m2000rt). These tests use recombinant proteins or viral synthetic peptides, encoded by both the structural regions (capsid, envelope) and nonstructural regions (NS3, NS4 and NS5) of the viral genome and $\operatorname{IgA}, \operatorname{IgM}$, IgG antibodies.

\subsubsection{Biochemical Examination}

a. Liver functions: including Aspartate Aminotransferase (AST) and Alanine Aminotransferase (ALT) levels, which were carried out using the fully automated chemical analyzer.

b. Determination of Glucose level by Colorimetric method

\subsection{Inclusion Criteria}

These criteria include patient age of 24 years or more, chronic hepatitis $\mathrm{C}$ diagnosed by $\mathrm{HCV}$ antibody ELISA positive and confirmed with HCV RNA PCR-positive.

\subsection{Exclusion Criteria}

In this study, we exclude: patients who received a treatment for 6 months, Patients were had chronic renal disease, liver disease, ischemic cardiovascular disease, organ transplantation, clinically relevant depression, uncontrolled diabetes, or severe hypertension with vascular complications, including retinopathy, known history of hemolytic anemia.

\subsection{Statistical Analysis}

Statistical analysis was performed using statistical MINITAB 13 was used for statistical analysis. All values are presented as mean \pm S.E.M.

\section{Results}

\subsection{Age Distribution of Patients}

Our study has shown that the risk of patients with hepatitis $\mathrm{C}$ is significantly higher in age range (46-65 years old) with $67 \%$. 


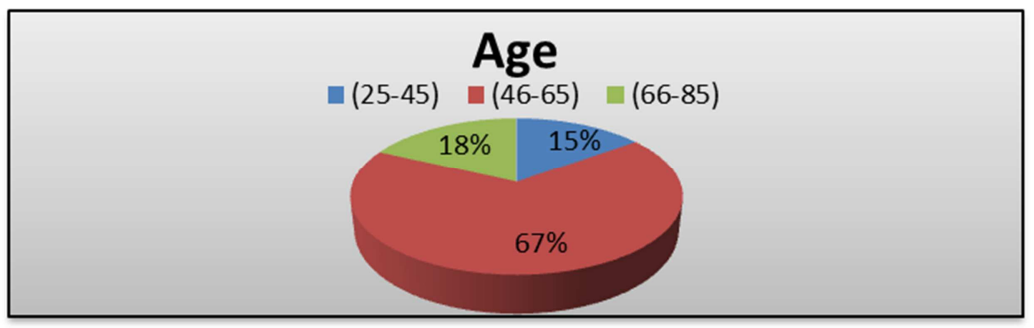

Figure 1. Age distribution of patients.

\subsection{Sex Distribution of Patients}

The number of female patients represents $82 \%$ of total cases. This number is relatively higher than the number of male patients represented $28 \%$.

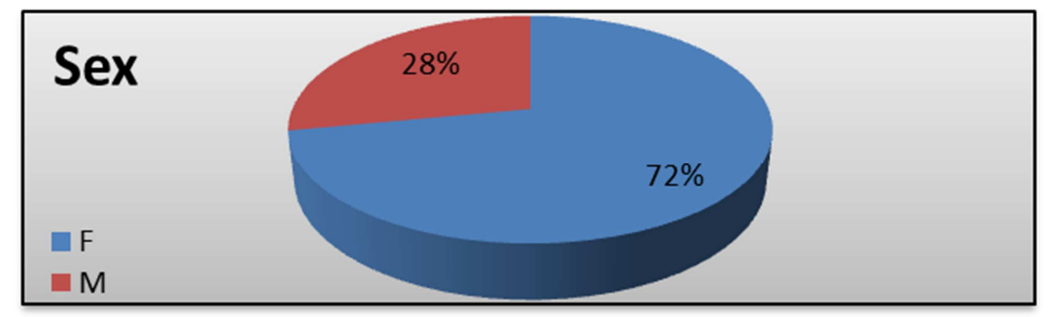

Figure 2. Sex distribution of patients.

\subsection{Genotype Distribution of Patients}

Our study showed that the most common genotype in our population is the sub genotype (1b) with $89 \%$ of the total number of cases.

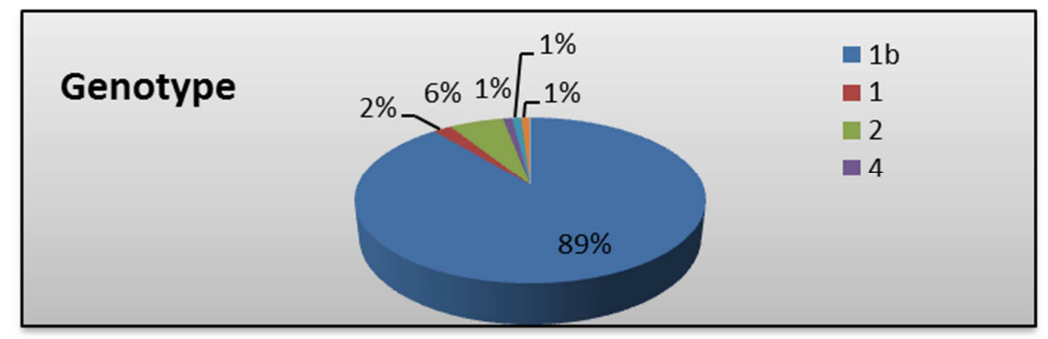

Figure 3. Genotype distribution of patients.

\subsection{Distribution According to Initial Viral Load}

The Viral load is determined using the Real Time- Polymerase Chain Reaction (RT-PCR). In our population, we took the value of $600,000 \mathrm{IU} / \mathrm{ml}(5.78 \mathrm{Log})$ to define two slices of viral load. This value constitutes, in recent studies, a limit-threshold between a so-called initial viral load and a high initial viral charge

Table 1. Initial viral load in studied population.

\begin{tabular}{lll}
\hline & low initial viral load & Hight initial viral load \\
\hline Initial viral load & $\geq 600.000 \mathrm{UI} / \mathrm{ml}(5.78 \mathrm{Log})$ & $<600.000 \mathrm{UI} / \mathrm{ml}(5.78 \mathrm{Log})$ \\
percentage \% & 39 & 61 \\
\hline
\end{tabular}

\subsection{Hematological Study}

\subsubsection{Variation of Erythrocyte Parameters in Control, Patients and Treated Subjects}

The statistical analysis of our results shows:

1. A significant decrease in the number of red blood cell (RBCs) and the hemoglobin ( $\mathrm{Hgb}$ ) content, as well as the percentage of hematocrit (HTC) in patients receiving dual therapy and triple therapy compared to healthy subjects

2. A significant increase of Mean Corpuscular Volume (MCV) and Mean corpuscular hemoglobin concentration (MCHC) and red cell distribution (RDW) in the subjects treated compared to healthy subjects. 
Table 2. Variation of Erythrocyte parameters in Control, patients and treated subjects in Weeks (2, 6, 8 12).

\begin{tabular}{|c|c|c|c|c|c|c|c|}
\hline Parameter & & $\operatorname{RBC}\left(10^{6} / \mathrm{mm}^{3}\right)$ & $\operatorname{MCV}\left(\mathbf{U} / \mathbf{m}^{3}\right)$ & HCT (\%) & Hgb (g/dl) & МCHC (pg) & RDW (\%) \\
\hline Control & & $4.254 \pm 0.378$ & $89.135 \pm 4.296$ & $38.774 \pm 3.740$ & $12.774 \pm 1.244$ & $29.560 \pm 1.488$ & $12.612 \pm 0.510$ \\
\hline Patients & & $4.577 \pm 0.390 * * *$ & $89.866 \pm 4.662 \mathrm{~ns}$ & $40.832 \pm 3.437 * *$ & $14.652 \pm 4.315 * *$ & $30.040 \pm 1.857 \mathrm{~ns}$ & $12.896 \pm 0.944 \mathrm{~ns}$ \\
\hline \multirow{4}{*}{$\begin{array}{l}\text { Treated } \\
\text { (sofosbuvir) }\end{array}$} & W2 & $4.810 \pm 0.579 * * *$ & $87.655 \pm 6.390 \mathrm{~ns}$ & $42.040 \pm 4.832 * *$ & $14.745 \pm 1.812 * * *$ & $29.290 \pm 6.835 \mathrm{Ns}$ & $13.4251 .265^{* * *}$ \\
\hline & W6 & $4.491 \pm 0.518^{*}$ & $88.895 \pm 5.778 \mathrm{~ns}$ & $40.176 \pm 4.162 \mathrm{~ns}$ & $14.419 \pm 1.720 * * *$ & $31.810 \pm 2.669 * * *$ & $13.362 \pm 1.416^{* *}$ \\
\hline & W8 & $4.555 \pm 0.522 * *$ & $90.160 \pm 5.833 \mathrm{~ns}$ & $40.975 \pm 4.911 *$ & $14.425 \pm 2.157 * * *$ & $31.685 \pm 3.312 * * *$ & $13.370 \pm 1.492 * *$ \\
\hline & W12 & $4.197 \pm 1.100 \mathrm{~ns}$ & $90.426 \pm 5.645 \mathrm{~ns}$ & $40.184 \pm 4.497 \mathrm{Ns}$ & $14.026 \pm 1.914 * *$ & $31.511 \pm 3.068 * * *$ & $13.363 \pm 1.353 * * *$ \\
\hline \multirow{3}{*}{$\begin{array}{l}\text { Treated } \\
\text { (sofosbuvir+ } \\
\text { ribavirin) }\end{array}$} & W2 & $4.326 \pm 0.637 \mathrm{~ns}$ & $91.550 \pm 5.554^{*}$ & $38.725 \pm 4.285 \mathrm{Ns}$ & $13.360 \pm 1.417 \mathrm{Ns}$ & $31.945 \pm 4.140 * *$ & $13.455 \pm 1.065 * * *$ \\
\hline & W8 & $2.830 \pm 0.5964 * * *$ & $93.310 \pm 8.353 \mathrm{~ns}$ & $35.889 \pm 4.151^{* *}$ & $12.133 \pm 1.384 \mathrm{Ns}$ & $31.511 \pm 3.905^{* *}$ & $14.178 \pm 1.765^{* * *}$ \\
\hline & W12 & $2.767 \pm 0.656^{* * *}$ & $94.350 \pm 9.839 * * *$ & $34.450 \pm 4.521 * * *$ & $11.470 \pm 1.582 * * *$ & $30.835 \pm 3.691 *$ & $14.830 \pm 2.526 * * *$ \\
\hline \multirow{4}{*}{$\begin{array}{l}\text { Treated } \\
\text { (sofosbuvir+ } \\
\text { ribavirin+ } \\
\text { interferon } \\
\text { peg) }\end{array}$} & W2 & $4.378 \pm 0.655 \mathrm{~ns}$ & $87.380 \pm 9.181 \mathrm{~ns}$ & $38.836 \pm 5.468 \mathrm{~ns}$ & $14.064 \pm 1.707 * *$ & $31.591 \pm 1.484 * * *$ & $13.091 \pm 1.416 \mathrm{~ns}$ \\
\hline & W6 & $3.711 \pm 0.810 * *$ & $89.790 \pm 2.950 \mathrm{~ns}$ & $33.800 \pm 7.258 * *$ & $11.970 \pm 2.096 \mathrm{~ns}$ & $31.750 \pm 2.033 * * *$ & $13.730 \pm 2.218^{* *}$ \\
\hline & W8 & $3.493 \pm 0.799 * * *$ & $93.450 \pm 6.797 * *$ & $32.350 \pm 6.125^{* * *}$ & $11.010 \pm 2.619 * *$ & $31.520 \pm 3.163 * *$ & $14.680 \pm 2.562 * * *$ \\
\hline & W12 & $2.001 \pm 0.546 * * *$ & $96.840 \pm 7.027 * *$ & $30.580 \pm 8.599 * * *$ & $10.270 \pm 1.747 * *$ & $31.660 \pm 2.171^{* * *}$ & $14.32 \pm 1.024 * * *$ \\
\hline
\end{tabular}

ns: not significant, $* \mathrm{P} \leq 0.05, * * \mathrm{p} \leq 0.01, * * * \mathrm{p} \leq 0.001$. Patients and treated groups vs Control groups

\subsubsection{Variation of Leukocyte Parameters in Control, Patients and Treated Subjects}

According to the result, we observe:

1. A very highly significant decrease $\leq 0.001$ of the number of white blood cells (WBC) and lymphocyte and monocyte in treated subjects compared control.

2. A very highly significant increase $(p \leq 0.001)$ in granulocytes in treated subjects (dual therapy "W8 and W12", triple therapy "W8") compared to healthy subjects

Table 3. Variation of leucocyte parameters in Control, patients and treated subjects in Weeks $((2,6,8,12)$.

\begin{tabular}{|c|c|c|c|c|c|}
\hline & parameter & WBC $\left(10^{3} / \mathrm{mm}^{3}\right)$ & Lymphocyte (\%) & Monocyte (\%) & Granulocyte (\%) \\
\hline \multirow{6}{*}{ Treated (sofosbuvir) } & Control & $6.539 \pm 1.687$ & $35.361 \pm 8.606$ & $14.492 \pm 3.746$ & $50.247 \pm 8.829$ \\
\hline & Patients & $6.490 \pm 1.464 \mathrm{~ns}$ & $35.736 \pm 6.124 \mathrm{~ns}$ & $11.136 \pm 3.432 * * *$ & $55.039 \pm 6.992 * *$ \\
\hline & W2 & $6.843 \pm 2.22 \mathrm{Ns}$ & $35.915 \pm 7.321 \mathrm{Ns}$ & $7.816 \pm 1.510 * * *$ & $57.600 \pm 7.163 * *$ \\
\hline & W6 & $6.842 \pm 1.896 \mathrm{Ns}$ & $36.367 \pm 7.213 \mathrm{Ns}$ & $7.427 \pm 2.299 * * *$ & $56.195 \pm 7.991 * *$ \\
\hline & W8 & $6.449 \pm 1.716 \mathrm{Ns}$ & $37.424 \pm 8.732 \mathrm{Ns}$ & $7.430 \pm 2.123 * * *$ & $54.991 \pm 8.358^{*}$ \\
\hline & W12 & $6.499 \pm 1.647 \mathrm{Ns}$ & $38.574 \pm 8.783 \mathrm{Ns}$ & $7.184 \pm 2.478 * * *$ & $53.874 \pm 9.375 \mathrm{Ns}$ \\
\hline \multirow{3}{*}{$\begin{array}{l}\text { Treated (sofosbuvir+ } \\
\text { ribavirin) }\end{array}$} & W2 & $6.027 \pm 1.459 \mathrm{Ns}$ & $34.875 \pm 3.638 * *$ & $8.695 \pm 2.970 * * *$ & $57.455 \pm 9.342 * *$ \\
\hline & W8 & $5.528 \pm 1.390^{*}$ & $33.739 \pm 2.733 \mathrm{Ns}$ & $7.194 \pm 2.532 * * *$ & $58.472 \pm 9.862 * * *$ \\
\hline & W12 & $5.615 \pm 2.031 *$ & $33.200 \pm 2.576 \mathrm{Ns}$ & $9.850 \pm 3.769 * * *$ & $57.72 \pm 7.365 * * *$ \\
\hline \multirow{4}{*}{$\begin{array}{l}\text { Treated (sofosbuvir+ } \\
\text { ribavirin+ interferon peg)) }\end{array}$} & W2 & $4.415 \pm 1.875^{* * *}$ & $35.627 \pm 2.463 * * *$ & $13.660 \pm 2.445 \mathrm{Ns}$ & $50.21 \pm 12.65 \mathrm{NS}$ \\
\hline & W6 & $4.403 \pm 1.508 * * *$ & $34.780 \pm 2.644 * * *$ & $5.270 \pm 3.175 * * *$ & $50.47 \pm 9.329 \mathrm{Ns}$ \\
\hline & W8 & $4.055 \pm 1.605^{* * *}$ & $33.810 \pm 3.441 \mathrm{~ns}$ & $5.620 \pm 2.749 * * *$ & $53.97 \pm 10.445 \mathrm{Ns}$ \\
\hline & W12 & $4.125 \pm 1.481 * * *$ & $33.690 \pm 3.201 \mathrm{Ns}$ & $7.890 \pm 3.205^{* * *}$ & $55.140 \pm 8.368 * * *$ \\
\hline
\end{tabular}

ns: not significant, ${ }^{*} \mathrm{P} \leq 0.05, * * \mathrm{p} \leq 0.01, * * * \mathrm{p} \leq 0.001$. Patients and treated groups vs Control groups, W: Week

\subsubsection{Variation of Thrombocyte Parameters in Control, Patient and Treated Subjects}

The statistical analysis of our results shows:

1. * A very highly significant decrease $(\mathrm{p} \leq 0.001)$ in the number of platelets (PLT) in the subjects treated ("W2, W6, W8" dual therapy) and ("W6" triple therapy) compared with healthy subjects.

2. * A very highly significant increase $(\mathrm{p} \leq 0.001)$ in mean platelet volume (MPV) in treated subjects (Monotherapy "W2" and (dual therapy "W2 and W12") compared to healthy subjects.

Table 4. Variation of Thrombocyte parameters in Control, patients and treated subjects in Weeks (2, 6, 8, 12).

\begin{tabular}{|c|c|c|c|}
\hline & Parameters & PLT $\left(10^{3} / \mathrm{mm}^{3}\right)$ & $\operatorname{MPV}\left(10^{3} / \mathrm{mm}^{3}\right)$ \\
\hline \multirow{6}{*}{ Treated (sofosbuvir) } & Control & $235.04 \pm 55.7$ & $6.539 \pm 1.687$ \\
\hline & Patients & $233.96 \pm 54.42 \mathrm{~ns}$ & $6.490 \pm 1.464 \mathrm{~ns}$ \\
\hline & W2 & $243.70 \pm 77.60 \mathrm{~ns}$ & $8.6200 \pm 0.9747 * * *$ \\
\hline & W6 & $232.76 \pm 77.50 \mathrm{~ns}$ & $7.9776 \pm 1.1490 \mathrm{~ns}$ \\
\hline & W8 & $226.449 \pm 71.6 \mathrm{~ns}$ & $8.1900 \pm 1.0125 \mathrm{~ns}$ \\
\hline & W12 & $250.21 \pm 70.4 \mathrm{~ns}$ & $8.1579 \pm 1.2153 \mathrm{~ns}$ \\
\hline \multirow{3}{*}{ Treated (sofosbuvir+ribavirin) } & W2 & $154.00 \pm 56.88 * * *$ & $9.060 \pm 1.496^{* * *}$ \\
\hline & W8 & $171.33 \pm 58.46^{* * *}$ & $8.366 \pm 1.4765 \mathrm{~ns}$ \\
\hline & W12 & $172.35 \pm 54.98 * * *$ & $8.965 \pm 1.2971 * * *$ \\
\hline
\end{tabular}




\begin{tabular}{|c|c|c|c|}
\hline & Parameters & PLT $\left(10^{3} / \mathrm{mm}^{3}\right)$ & $\operatorname{MPV}\left(10^{3} / \mathrm{mm}^{3}\right)$ \\
\hline \multirow{4}{*}{$\begin{array}{l}\text { Treated (sofosbuvir }+ \text { ribavirin }+ \\
\text { interferon peg) }\end{array}$} & W2 & $178.27 \pm 95.04^{* *}$ & $8.645 \pm 1.4341^{* *}$ \\
\hline & W6 & $160.00 \pm 60.64 * * *$ & $8.680 \pm 1.5091^{* *}$ \\
\hline & W8 & $198.60 \pm 92.45 \mathrm{Ns}$ & $8.700 \pm 1.713^{* *}$ \\
\hline & W12 & $177.70 \pm 81.52 * *$ & $8.690 \pm 1.540 * *$ \\
\hline
\end{tabular}

ns: not significant, $* \mathrm{P} \leq 0.05, * * \mathrm{p} \leq 0.01, * * * \mathrm{p} \leq 0.001$. Patients and treated groups vs Control groups, W: Week

\subsection{Variation of Biochemical Parameters in Control, Patients and Treated Subjects}

The statistical analysis of our results shows:

1. A very highly significant increase the ALT and AST in patientscompared to control group and a significant decrease in treated group.

2. A significant increase of Glycemia level of treated group receiving tripl therapy in week 12 compared to control group.

Table 5. Variation of biochemical parameters in Control, patients and treated subjects in Weeks $(2,6,8,12)$.

\begin{tabular}{lllll}
\hline Parameter & & ALT(UI/L) & AST (UI/L) & Glycemia (g/l) \\
\hline Control & & $18.49 \pm 6.39$ & $119.30 \pm 5.97$ & $0.9286 \pm 0.1181$ \\
Patients & & $48.92 \pm 49.65^{* * *}$ & $46.23 \pm 42.83^{* * *}$ & $1.0056 \pm 0.3166 \mathrm{~ns}$ \\
& W2 & $31.673 \pm 12.87^{* *}$ & $33.895 \pm 15.182^{* * *}$ & $0.9845 \pm 0.3268 \mathrm{~ns}$ \\
Treated (sofosbuvir) & W6 & $27.61 \pm 17.17 * * *$ & $27.091 \pm 15.681^{* *}$ & $0.966 \pm 0.2338 \mathrm{~ns}$ \\
& W8 & $18.294 \pm 6.362 \mathrm{~ns}$ & $20.728 \pm 7.079 \mathrm{~ns}$ & $0.986 \pm 0.2948 \mathrm{~ns}$ \\
& W12 & $17.054 \pm 7.087 \mathrm{~ns}$ & $18.435 \pm 7.985 \mathrm{~ns}$ & $0.968 \pm 0.2740 \mathrm{~ns}$ \\
Treated & W2 & $37.23 \pm 23.25^{* * *}$ & $44.71 \pm 25.64^{* * *}$ & $0.947 \pm 0.1433 \mathrm{~ns}$ \\
(sofosbuvir+ribavirin) & W6 & $28.06 \pm 22.77^{* *}$ & $34.96 \pm 22.68^{* * *}$ & $1.141 \pm 0.468^{* *}$ \\
& W8 & $23.117 \pm 13.430 \mathrm{~ns}$ & $26.680 \pm 10.259^{* * *}$ & $0.955 \pm 0.1266 \mathrm{~ns}$ \\
& W12 & $21.442 \pm 7.301 \mathrm{~ns}$ & $20.341 \pm 7.679 \mathrm{~ns}$ & $0.944 \pm 0.1320 \mathrm{~ns}$ \\
Treated (sofosbuvir + & W6 & $25.041 \pm 7.141^{* *}$ & $27.298 \pm 10.002^{* * *}$ & $1.129 \pm 0.758^{* *}$ \\
ribavirin + interferon peg) & W8 & $24.473 \pm 9.117 \mathrm{~ns}$ & $24.154 \pm 14.130 \mathrm{~ns}$ & $1.230 \pm 0.7918^{* *}$ \\
& W12 & $20.161 \pm 9.288^{* *}$ & $26.331 \pm 11.431^{* *}$ & $1.305 \pm 0.9788^{* *}$ \\
\hline
\end{tabular}

ns: not significant, $* \mathrm{P} \leq 0.05,{ }^{* *} \mathrm{p} \leq 0.01,{ }^{* * *} \mathrm{p} \leq 0.001$. Patients and treated groups vs Control groups, W: Week

\section{Discussion}

In our study we followed 300 Algerian patients infected by chronic hepatitis $\mathrm{C}$ receiving oral Pegylated interferon, Sofosbuvir and Ribavirin for 12 weeks. The results showed that the most affected age group by HCV is that between (4665 years) with a percentage of $67 \%$ this may be due to the low immunity with advanced age. These data are correlated with a country classification by prevalence and its age distribution based on an analysis of published studies [15] which classify Algeria and number of sub-Saharan African countries in type 3 corresponding to a high prevalence in each age group and increasing with age as a result of predominant iatrogenic transmission (use of non-sterile exposure to medical care, therefore with age, and which is currently poorly controlled. In addition, we observed in our population that women represented a high number (82\%) compared to men in the Hepatitis C affected population. Thus, our sample shows a clear predominance of subgenotype $1 \mathrm{~b}(89 \%)$ followed by other types of subgenotypes. These results are in agreement with those of Debbeche et al (2013); Hmida et al (1995) and Rouabhia et al (2013) [16-18].

The determination takes a major importance in the pretherapeutic assessment and in the therapeutic follow-up of patients with chronic hepatitis $C$. In our series quantitative RT-PCR was carried out in all patients, it revealed: high viral load (CV $\geq 600,000 \mathrm{IU} / \mathrm{ML}$ ) in $61 \%$ of patients tested, a low viral charge in $39 \%$.

Results from the study showed a significant decrease in the number of RBCs and the Hgb level, as well as the percentage of HTC in patients receiving dual therapy and triple therapy compared to healthy subjects, which shows the presence of anemia in these patients. This erythrocyte decrease was explained by the increase in plasma volume and the expansion of the red blood cell mass with regard to hematocrit levels and hemoglobin concentrations below the cut-off point makes anemia known. In addition, our results also show a significant increase in $\mathrm{MCV}, \mathrm{MCHC}$, and RDW levels, which indicates hemolytic anemia.

In addition, we found that only dual therapy (Sofosbuvir+Ribavirin) and triple therapy (Sofosbuvir +Ribavirin+INFpeg) that increase the risk of anemia against monotherapy no risk observed, this is mainly related to the action of Ribavirin and Pegylated Interferon or to because of genetic predisposition.

Ribavirin, is a nucleoside analogue of guanosine, after oral administration, he was absorbed into the proximal small bowel by sodium carriers [19]. After this absorption, the average time to reach the maximum concentration is 1.5 hours, followed by a rapid distribution phase and a prolonged phase of elimination [20]. Ribavirin is then transported to all human cells and then phosphorylated, ribavirin triphosphate is the major metabolite; transport to the extracellular environment requires dephosphorylation of ribavirin. This property is deficient at the erythrocyte level, which explains 
the lack of dephosphorylation of the molecule and therefore its accumulation in erythrocytes which induces erythrocyte hemolysis [21].

Interferon also contributes to a lesser degree to anemia by acting as a myelosuppressor and inhibiting the production of erythropoietin, in addition, Pegylated interferon can increase the apoptosis of precursor cells of the erythroblastic lineage, induce autohemolysis.-immune and aggravate renal function [22]. In addition, Kamatani et al [23] was found that genetic variants that cause deficiencies in the production of an enzyme called inosine triphosphate pyrophosphatase gene affect the ribavirin that induces anemia. Our results are similar to work of Watson et al. [24] who reported that $39 \%$ of patients treated with interferon and ribavirin develop anemia, and further agreed with De Franceschi et al; (2000) Krishnan et al (2011) and Sulkowski et al (2003) [25-27]

Results from the study showed the presence of thrombocytopenia in patients receiving dual and triple therapy that was revealed by the decrease in platelet count. This is related to the interferon action myelosuppressor which suppresses the expression of transcription factors regulating latestage megakaryopoiesis, such as GATA-1, p45NF-E2, Maf G which reduces the number of PLT in the peripheral blood but not megakaryocytes [28]. Moreover, in 2010 Stellacci et al. [29] cited that Interferon inhibits the maturation of demarcation membranes in the megakaryocyte. The autoimmune mechanism may also be involved [30] due to thetransduction of the relative thrombopoietin signal in megakaryocytes [31]. Approximately $46 \%$ of patients receiving IFN and ribavirin had thrombocytopenia with a platelet count of less than 500 requiring dose reduction during treatment [32] so that low platelet count increases the incidence of thrombocytopenia associated with antiviral treatment [33].

The results are in agreement with the works of:

- Manns et al (2001) [34] and Fried et al (2002) [35] who have been found thrombocytopenia in $10-50 \%$ of Pegylated inteferon-treated hepatitis C cases, Nemr et al (2016) [36] who found that Ribavirin treatment induces thrombocytopenia in Egyptian patients with hepatitis C. Nese et al (2009) [37] who have been shown the presence of thrombocytopenia after treatment of patients with Ribavirin and Pegylated interferon.

In the present study, we found a leukopenia in treated patients, which translates into a very highly significant decrease in the number of WBC and lymphocytes as well as monocytes, and a very significant increase in granulocytes. Neutropenia in $\mathrm{HCV}$ patients receiving interferon and ribavirin showed that $8 \%-24 \%$ of these patients develop neutropenia. They showed that neutrophils and absolute lymphocytes generally decrease by $30 \%$ to $50 \%$ of the baseline during treatment [38]. Although neutropenia is common during $\mathrm{HCV}$ treatment, it was not considered common and associated with infections [39].

Regarding the biochemical parameters we found in our study a very highly significant increase in the levels of ALT and AST in patients which reflects the presence of a cell injury, especially in the liver. On the other hand, we found a decrease of ALT and AST in the treated patients which show the effectiveness of the treatments used. It has been reported that in patients with chronic hepatitis $\mathrm{C}$, treatment with ribavirin decrease serum hepatic transaminase levels by decreasing hepatic inflammation and necrosis [40, 41].

Treatment of HCV with Alfa-interferon has also been reported to induce autoimmune diseases such as Hashimoto's thyroiditis and immune-mediated diabetes [42, 43]. Most reports of diabetes mellitus in this situation occur within a few weeks after starting treatment [44, 45]. Tosone et al (2007) [46] were reported the case of a 42years old woman with chronic hepatitis C (genotype 1), who started in June 2004 treatment with PEG-IFN $\alpha$ associated with ribavirin. Two months later, she stopped treatment because the appearance of diabetes with ketoacidosis, and insulin therapy began.

\section{Conclusion}

Chronic hepatitis $\mathrm{C}$ virus (HCV) infection is one of the most widespread chronic liver diseases. More than 300 million per-sons are affected worldwide. Despite major advances in antiviral treatments, Sofosbuvir, Interferon and Ribavirin remains the current anti-HCV therapy in Algeria and it is associated with certain hematologic adverse effects. In this concurrent comparative study the incidence of major hematologic side effects like anemia, leucopenia and thrombopenia are increased in patients treated by dual (Sofosbuvir + Ribavirin) and triple therapy (Sofosbuvire + ribavirine + interferon).

Levels of RBC, WBC, PLT counts were monitored for hematologic adverse effects, whereas, ALT, AST levels were monitored for efficacy of treatments.

A highly significant decrease in Red blood cells, hemoglobin and a significant decrease in White blood cells and platelets was observed in week 12 of therapy.

This hematological toxicity is the most cause of discontinuation of treatments in patients with chronic hepatitis $\mathrm{C}$.

\section{Acknowledgements}

Many thanks to all who made this research possible, including all the personnel of hematology and virology services of CHERIA and BAKARIA Hospitals and PASTEUR Institute of Algeria.

\section{Conflicts of Interest}

I declare that I have no relevant competing interests.

\section{Funding}

No specific funding was received for this research.

\section{Ethics Approval}

Ethical approval was not needed as local formularies 
throughout in Algeria are publically available documents included in the freedom of information scheme.

\section{References}

[1] World Health Organization Hepatitis C Factsheet; available online at:http://www.who.int/news-room/factsheets/detail/hepatitis-c;lastaccessed on July 1, 2018.

[2] AASLD. Recommendations for Testing, Managing, and Treating Hepatitis C; available online at: https://www.hcvguidelines.org/; last accessed on July 1, 2018.

[3] EASL recommendations on treatment of hepatitis C. $J$ Hepatol; 69(2):461-511, 2018.

[4] Manns MP, Buti M, Gane E, Pawlotsky J-M, Razavi H, Terrault N, et al. Hepatitis C virus infection. Nat Rev Dis Prim 3:17006, 2017.

[5] Golabi P, Sayiner M, Bush H, Gerber L, Younossi Z. Patientreported outcomes and fatigue in patients with chronic hepatitis C infection. Clin Liver Dis 21:565-578, 2017.

[6] Gane E, Lawitz E, Pugatch D, Papatheodoridis G, Brau N, Brown A, et al. Glecaprevir and pibrentasvir in patients with $\mathrm{HCV}$ and severe renal impairment. N Engl J Med. 377:1448-1455, 2017.

[7] Curry MP, O'Leary JG, Bzowej N, Muir AJ, Korenblat KM, Fenkel JM, et al. Sofosbuvir and velpatasvir for HCV in patients with decompensated cirrhosis. $N$ Engl J Med 373:2618-2628, 2015.

[8] Calleja JL, Crespo J, Rincon D, Ruiz-Antoran B, Fernandez I, Perello C, et al. Effectiveness, safety and clinical outcomes of direct-acting antiviral therapy in HCV genotype 1 infection: results from a Spanish real-world cohort. J Hepatol 66:1138$1148,2017$.

[9] Backus LI, Belperio PS, Shahoumian TA, Loomis TP, Mole LA. Real-world effectiveness and predictors of sustained virological response with alloral therapy in 21, 242 hepatitis C genotype-1 patients. Antivir Ther 22:481-493, 2017.

[10] Pascasio JM, Vinaixa C, Ferrer MT, Colmenero J, Rubin A, Castells L, et al. Clinical outcomes of patients undergoing antiviral therapy while awaiting liver transplantation. $J$ Hepatol; 67:1168-1176, 2017.

[11] Younossi Z, Henry L. Systematic review: patient-reported outcomes in chronic hepatitis $\mathrm{C}$ - the impact of liver disease and new treatment regimens. Aliment Pharmacol Ther; 41:497-520, 2015.

[12] Martin P, Jensen D: Ribavirin in the Treatment of Chronic Hepatitis C. J Gastroenterol Hepatol, 23:844-855, 2008.

[13] Lashin AH, Shaheen YA, Metwally MA, El-Feky HM, Hegab MF \& Abbas SM. Incidence and predictors of hematological side effects in chronic HCV Egyptian patients treated with PEGylated interferon and ribavirin. Indian $J$ Gastroenterol 32(5):316-323, 2013.

[14] Pontali E, Angeli E, Cattelan AM, Maida I, Nasta P, Verucchi $\mathrm{G}$, et al. Cytopenias during treatment of HIV-HCVcoinfection with pegylated interferon and ribavirin: Safety analysis of the OPERA study. Antiviral Therapy;20(1):39-48, 2015.
[15] Wasley A \& Alter MJ. Epidemiology of hepatitis C: geographic differences and temporal trends. Semin Liver Dis.; 20(1):1-16, 2000

[16] Debbeche R, Said Y, Ben Temime H, El Jery K, Bouzaidi S, Salem M \& Najjar T. Epidemiology of hepatitis $\mathrm{C}$ in Tunisia. Tunis Med; 91(2):86-90, 2013.

[17] Hmida S, Mojaat N \& Chaouchi E. HCV antibodies in hemodialyzed patients in Tunisia. Pathol Biol.;43:581-3, 1995.

[18] Rouabhia S, Sadelaoud M, Chaabna-Mokrane K, Toumi W\&Abenavoli L. Hepatitis $\mathrm{C}$ virus genotypes in north astern Algeria: A retrospective study. World J Hepatol; 5(7): 393 397, 2013.

[19] Glue P. The clinical pharmacology of ribavirin. Seminars in Liver Disease. 19: 17-24, 1999. Gordien E. Virus de l'hépatite C: dynamique, réplication intracellulaire. Elsevier SAS; 13-26, 2003.

[20] Khakoo, S., Glue P, Grellier L, Wells B, Bell A, Dash C, Murray-Lyon L, Lypnyj D, Flannery B, Walters K \& Dusheiko GM. Ribavirin and interferon alfa-2b in chronic hepatitis C:assessment of possible pharmacokinetic and pharmacodynamic interactions. Br J Clin Pharmacol; 46(6): 563-570, 1998.

[21] Dimitrow, Y, Heibel F, Marcellin L, Chantrel F, Moulin B \& Hanne D. Acute renal failure and nephrotic syndrome with alpha interferon therapy. Nephrol Dial Transplant;. 12:200-3, 1997.

[22] Balan V, Schwartz D, Wu GY, Muir AJ, Ghalib R, Jackson J, Keeffe EB, Rossaro L, Burnett A, Goon BL, Bowers PJ \& Leitz GJ.. Erythropoietic response to anemia in chronichepatitis $\mathrm{C}$ patients receiving combination pegylated interferon/ribavirin.; HCV Natural History Study Group. Am J Gastroenterol; 100(2):299-307, 2005.

[23] Kamatani N, Nakamura Y \& Miyakawa Y. Influence of inosine triphosphatase gene (ITPA) polymorphism on decrease of heamoglobin during treatment with pegylated interferon, ribavirin and telaprevir. Hepatol; 40 (5): 1450-1458, 2010.

[24] Watson J, Hassanein TI. \& Kayali Z. Prospects for hepatitis C virus therapeutics: Boceprvir and telaprevir as adjuvant therapy to the standard antiviral regimen. Curr Opin Investig Drug; 4 (6): 5705-5708, 2010.

[25] De Franceschi L, Fattovich G, Turrini F. \& al. Hemolytic anemia induced by ribavirin therapy in patients with chronic hepatitis $\mathrm{C}$ virus infection: role of membrane oxidative damage. Hepatology. 31: 997-1004, 2000.

[26] Krishnan SM \& Dixit NM. Ribavirin-Induced Anemia in Hepatitis C Virus Patients Under going Combination Therapy. PLoSComput Biol 7(2) e1001072, 2011.

[27] Sulkowski MS. Hepatotoxicity associated with antiretroviral therapy containing HIV-1 protease inhibitors. Semin Liver Dis. 23(2): 183-94, 2003.

[28] Abdel Hafez H, El Beshlawy M, Mabrouk M, El-Akel W, Awad T, Zayed N. \& Esmat G.. Hematological Side effects of Anti-viral Therapy in Egyptian Patients with Chronic Hepatitis C Virus. Am. J. Pharm Tech Res. 4(1): 2249-3387, 2014.

[29] Stellacci E, Test U, Petrucci E \&al. Interferon inhibits maturation of demarcation membranes in megakaryocytes. Biochem J; 377 (8): 367-378, 2010. 
[30] Mihai O, Cristina O \& Dan O. Thrombocytopenia in Chronic Hepatitis C. J Gastro intestine Liver Dis.; 19 (4), 381-385, 2010.

[31] Peck-Radosavljevic M, Wichlas M \&Pidlich J. Blunted thrombocytopenia response to interferon alpha induced thrombocytopenia during treatment for hepatitis C. Hepatology; 28(5):142-149, 2007.

[32] Renou C, Rosenthal E \& Cohen P. Incidence of thrompocytopenia in patients with hepatitis $\mathrm{C}$ virus infection receiving interferon therapy. A prospective multicenter study of 321 patients. Hepatology; 79 (13): 32-42, 2005.

[33] Dourakis SP, Deutsch M \& hadziyannis SJ. Thrombocytopenia and interferon therapy. J. Hepatol; 25(4): 972- 975, 2006.

[34] Manns M, Mc Hutchison JG, Gordon SC, Rustgi VK, Shiffman ML. \& Reindollar, R. Peg interferon alfa-2b plus ribavirin compared with interferon alfa- $2 b$ plus ribavirin for initial treatment of chronic hepatitis $\mathrm{C}$ : a randomised trial. Lancet; 358: 958-965, 2001.

[35] Fried MW, Shiffman ML, Reddy KR, Smith C, Marinos G \& Gonçales FL. Peg interferon alfa-2a plus ribavirin for chronic hepatitis C virus infection. N Engl J Med. 347:975-82, 2002.

[36] Nemr N, Kishk R \& Mandour M. Role of ITPA gene polymorphism in ribavirin-induced anemia and thrombocytopenia in Egyptian patients with chronic hepatitis C. Indian J Gastroenterol; (1):7-13, 2016.

[37] Nese N, Gupta R, Bui MH \& Amin MB. Carcinoma in situ of the urinary bladder: review of clinicopathologic characteristics with an emphasis on aspects related to molecular diagnostic techniques and prognosis. J Natl Compr Canc Netw; 7 (1): 48$57,2009$.

[38] Antonini MG, Babudieri S \& Maida I. Incidence of neutropenia and infections during combination treatment of chronic hepatitis $\mathrm{C}$ with pegylated interferon alpha plus ribavirin. Infection. 36 (4): 250-255, 2008.
[39] Navas S, Martin J. \& Quirogaa JA. Recombinant human granulocyte colony stimulating factor reduces hepatitis $\mathrm{C}$ virus replication in mononuclear cells from chronic hepatitis $\mathrm{C}$ patients. Cytokine. 8 (7): 313-317, 2010.

[40] Di Bisceglie AM, Conjeevaram HS, Fried MW, Sallie R, Park Y, Yurdaydin C, Swain M, Kleiner DE, Mahaney K \& Hoofnagle JH. Ribavirin as therapy for chronic hepatitis C. A randomized, double-blind, placebo-controlled trial. Ann Intern Med; 123: 897-903, 1995.

[41] Camps J., García N., Riezu-Boj JI., Civeira MP \& Prieto J. Ribavirin in the treatment of chronic hepatitis $\mathrm{C}$ unresponsive to alfa interferon. J Hepatol; 19:408-412, 1993.

[42] Allison MED, Wreghitt T, Palmer CR\& Alexander GJM. (1994). Evidence of a link between hepatitis C virus infection and diabetes mellitus in a cirrhotic population. J Hepatol 21:1135-1139, 1994.

[43] Radhakrishnan S, Upadhyay Nihar A, Mohan N, Dhar A, Walia HK. \& Zubaid G. Late Development of Diabetes mellitus after Interferon-Alfa and Ribavirin Therapy for Chronic Hepatitis C: A case report. Med PrincPract; 14(4):281-3, 2005.

[44] Caronia S, Taylor K, Pagliaro L, Carr C, Palazzo U, Petrik J, O'Rahilly S, Shore S, Tom BD, Alexander GJ. Further evidence for an association between non-insulin dependent diabetes mellitus and chronic hepatitis $\mathrm{C}$ virus infection. Hepatology; 30 (4):1059-63, 1999.

[45] Fabris P, Betterle C, Greggio NA, Zanchetta R, Bosi E \& Biasin MR. Insulin-dependent diabetes mellitus during alfainterferon therapy for chronic viral hepatitis. $J$ Hepatol; 28: 514-517, 1998

[46] Tosone G, Borgia IG, Gentile R, Cerini MC, Conte D, Orlando R \& Piazza, M. A case of pegylated interferon alpharelated diabetic ketoacidosis: can this complication be avoided? Acta Diabetologica; 44 (3): 167-169, 2007. 